RESEARCH STUDIES ON THE LIFE CYCLE OF INFECTIOUS HEMATOPOIETIC NECROSIS VIRUS

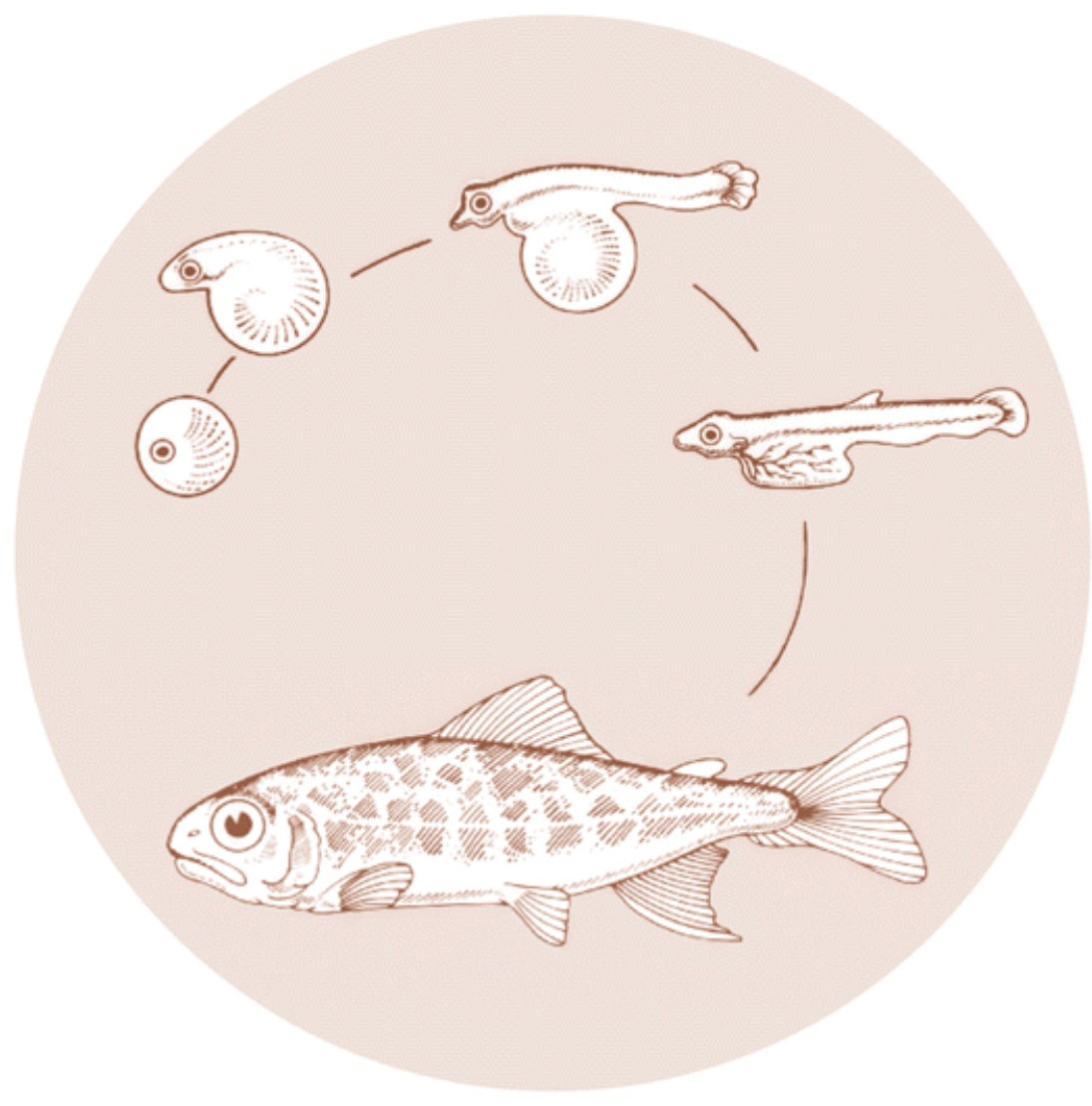

DOE/BP-92431-1 
This report was funded by the Bonneville Power Administration (BPA), U.S. Department of Energy, as part of BPA's program to protect, mitigate, and enhance fish and wildlife affected by the development and operation of hydroelectric facilities on the Columbia River and its tributaries. The views of this report are the author's and do not necessarily represent the views of BPA.

This document should be cited as follows:

Sandra S. Ristow, Arnzen, J. M., Washington State University - Dept. of Animal Science; Jo-Ann C. Leong, Oregon State University - Dept. of Microbiology, Research Studies on the Life Cycle of Infectious Hematopoietic Necrosis Virus, 1990, to Bonneville Power Administration, Portland, OR, Contract DE-FG79-89BP92431, Project 88-152, 59 electronic pages (BPA Report DOE/BP-92431-1)

This report and other BPA Fish and Wildlife Publications are available on the Internet at:

\section{http://www.efw.bpa.gov/cgi-bin/efw/FW/publications.cgi}

For other information on electronic documents or other printed media, contact or write to:

Bonneville Power Administration Environment, Fish and Wildlife Division

P.O. Box 3621

905 N.E. 11th Avenue

Portland, OR 97208-3621

Please include title, author, and DOE/BP number in the request. 


\title{
RESEARCH STUDIES ON THE LIFE CYCLE OF INFECTIOUS HEMATOPOIETIC NECROSIS VIRUS
}

\author{
Prepared by: \\ Sandra S. Ristow \\ Jeanene M. arnzen \\ Washington State University \\ Department of Animal Science \\ Jo-Ann C. Leong \\ Oregon State University \\ Department of Microbiology
}

\author{
Prepared for: \\ U.S. Department of Energy \\ Bonneville Power Administration \\ Environment, Fish and Wildlife \\ PO Box 3621 \\ Portland, Oregon 97208 \\ Project No. $88-152$ \\ Contract No. DE-FG79-89BP92431
}

November 1990 
Rage Ne.

INTRODUCTION

1

LITERATURE REVIEW 2

MATERIALS AND METHODS 3

Virus 3

Antisera 4

Monoclonal Antibodies 4

Infection and Labeling of Cultures $\mathbf{4}$

Immunoprecipitation of Viral Proteins 5

SDS Polyacrylamide Gel Electrophoresis 6

$\begin{array}{ll}\text { Fluorescence Analysis of Isolates } & 6\end{array}$

Plaque Reduction Assay 7

Competition between Monoclonal Antibodies 8

RESULTS 9

Serum Neutralization by Monoclonal Antibodies 9

Fluorescence Assays 11

Molecular Weight Typing of Viral Polypeptides 13

DISCUSSION 15

$\begin{array}{ll}\text { LITERATURE CITED } & 19\end{array}$

APPENDICES

Table 1. Partial List of Isolates Analayzed by 53

Table 2. Reactions of Recent Isolates 55 


\section{LIST OF TABLES}

Table

1

2

3

4

5

6
Standard Isolates

Serum Neutralization

Inhibition of ${ }^{125}$ I Labeled Antibodies

Monoclonal Antibodies

Nucleoprotein Molecular Weights

Molecular Weights of IHNV Glycoproteins
Page $\mathrm{No}$,

21

23

25

28

31

33 
We owe our thanks to the many researchers and hatchery personnel who helped us gather virus isolates to complete this work. Among those contributing isolates were: Jo-Ann Leong and John Rohovec of Oregon State University; Joe Lientz and Colleen Hesson of Dworshak National Fish Hatchery; Scott LaPatra, Oregon Department of Fish and Wildlife; Warren Groberg, Oregon Department of Fish and Wildlife, Eastern Oregon State College; Robert Busch, Clear Springs Trout Co.; Steve Roberts, Washington Department of Wildlife; Scott Foote, Coleman National Fish Hatchery; Kent Hauck, Idaho Department of Fish and Game; and Garth Traxler, Department of Fisheries and Oceans, Nanaimo, B. C. Canada.

This work has been supported by the Bonneville Power Administration program DE-FG79-89BP92431, USDA grant 87-CRSR-23039, by the Washington Technology Center and by grants 87-CRSR2-3219 and 88-38500-4027 from the USDA to the Western Regional Aquaculture Consortium. 


\section{ABSTRACT}

Seventeen strains of infectious hematopoietic necrosis virus (IHNV) from different geographical regions and from different fish stocks were typed by polyacrylamide gel electrophoresis, indirect fluorescence with 27 monoclonal antibodies against both the $\mathrm{G}$ and $\mathrm{N}$ proteins of the virus, and by serum neutralization with six monoclonal anti-glycoprotein antibodies. In addition, many other IHNV isolates, including those from the original electropherotyping studies (Hsu et al., 1986) and recent isolates, have been examined by indirect fluorescence with the monoclonal antibodies. Some minor variations in nucleoprotein molecular weights were found among the isolates. Studying the isolates, however, with the antibodies has shown that a greater amount of variation exists between isolates than was first predicted by the application of the polyacrylamide technique. Isolates within electrophoretic types I-V may be further classified according to their reacticns with the monoclonal antibodies in indirect fluorescence.

Serum neutralization with selected anti-glycoprotein antibodies in conjunction with fluorescence analysis confirms one of the original findings of Hsu et al. (1986) that two different species in a single facility can be infected with the same isolate. Variation among isolates as measured by reactivity with the monoclonal library appears to be greater within the G protein than within the $\mathrm{N}$ protein sequence. 
INTRODUCTION

The characterization of 15 different strains of IHNV from different locations and different species/stocks of salmonid hosts was conducted in the studies presented here. These viral strains were typed according to their electrophoretic migration in sodium dodecyl sulfate polyacrylaaide gel electrophoresis (SDS-PAGE.) and their reaction with monoclonal antibodies to the viral $\mathrm{N}$ and $\mathrm{G}$ proteins. The 15 IHNV strains were selected from the Columbia River Basin and from previously characterized strains which served as standards in the study. Included were six chinook salmon, five steelhead trout, two sockeye salmon, one kokanee, and three rainbow trout isolates from diverse geographic regions.

The aim of the study was to determine whether there were virion protein differences among IHNV strains and whether these differences correlated with virulence data. For example, the study would provide data that would make the determination that a particular monoclonal antibody type or electrophoretic type is characteristic of a virus virulent for chincok salmon. The work was contracted to provide the molecular marker data on the 15 different IHNV strains that will be tested for virulence in the Bcnneville Power Administration sponsored project "Research Studies on the Life Cycle of Infectious Hematopoietic Necrosis Virus." 


\section{LITERATURE REVIEW}

Electropherotyping infectious hematopoietic necrosis virus (IHNV) by incorporation of ${ }^{35} \mathrm{~S}$ into infected cell cultures followed by sodium dodecyl sulfate polyacrylamide gel electrophoresis on the radioactively labeled polypeptides has become a standard method for classifying the virus (Hsu et al., 1986). This method has previously yielded important information concerning the biology of the virus including: (1) the observation that many salmonid species in a geographical area in which an outbreak occurs are infected with IHNV possessing polypeptides of identical molecular weight, and (2) that the same IHNV protein pattern is exhibited by infected parents and progeny

The method has shown that Type I virus previously predominated in Canada, Washington and in Oregon, while Type II virus appeared further inland and is now endemic in rainbow trout (oncorhynchus mykiss) in southern Idaho. Types III and IV virus are coastal forms which predominate in chinook salmon (Oncorbynchus tshawutscha) in Oregon and California. The ability of SDS-PAGE electropherotyping to distinguish between strains of IHNV primarily rests with the determination of the molecular weight of the nucleoprotein (N). The glycoprotein (G) molecular weight of most strains is relatively constant at $67 \mathrm{kDa}$, with the exception of those isolates classified as Type IV, whose G protein molecular weight is $70 \mathrm{kDa}$. 
A number of monoclonal antibodies have been produced to IHNV. The first of these antibodies was described by schultz et al. (1985). Since that time, Winton et al. (1988) developed antibodies to the G proteins of several strains and used them to classify other strains of IHNV in serum neutralization studies. Ristow and Arnzen (1989) produced monoclonal antibodies to the nucleoproteins of several isolates and have concluded that electrophoretic Type II virus can be distinguished by indirect immunofluorescence with a single monoclonal antibody.

Monoclonal antibodies have been used by several laboratories to detect the presence and distinguish between strains of IHNV by means of fluorescence (LaPatra et al., 1989; Ristow and Arnzen, 1989) and dot immunoassay (Schultz et al., 1989).

\section{MATERIALS AND METHODS}

virus. Seventeen standard isolates listed in Table 1 were supplied frozen on dry ice by Jo-Ann Leong and John Rohovec, Oregon State University, Corvallis, OR. Additional isolates which were tested in the extended fluorescence assays described at the end of this report were supplied by Jo-Ann Leong and John Rohovec of Oregon State University, Corvallis, OR; Joe Lientz and Cclleen Hesson of Dworshak National Fish Hatchery, Ahsahka, ID; Scott LaPatra, Oregon Department of Fish and Wildlife, Corvallis, OR; Warren Groberg, Oregon Department of Fish and Wildlife, Eastern Oregon State College, LaGrande, OR; Robert Busch, Clear Springs Trout Co., Buhl, ID; Steve Roberts, Washington Department of Wildlife, Wenatchee, WA; Scott Foote, 
Coleman National Fish Hatchery, Anderson, CA; Kent Hauck, Idaho Department of Fish and Game, Eagle, Idaho; and Garth Traxler, Department of Fisheries and Oceans, Nanaimo, B. C., Canada.

Antisera. A polyclonal antiserum to the Round Butte strain of IHNV, and monospecific antisera to the $G$ and $N$ proteins of IHNV came from Jo-Ann Leong and H. Mark Engelking.

Monoclonal Antibodies. Monoclonal antibodies to the $\mathrm{G}$ and $\mathrm{N}$ proteins of several strains of IHNV [Hagerman 039-82 SR, Coleman 2 (CO2), Feather River (FR), and Cedar River (CD) and Dworshak 2 (DW) 1, were produced by fusion of immunized spleen cells with the P3X63-Ag8.653 BALB/C mouse myeloma by as described in a previous publication (Ristow and Arnzen, 1989).

Infection and Labeling of Cultures. A $75 \mathrm{~cm}^{2}$ flask of CHSE-214 cells was infected with a single isolate of IHNV at a multiplicity of 10 . The virus sample was adsorbed to the monolayer for 1 hour at $16^{\circ} \mathrm{C}$. Then $15 \mathrm{ml}$ of methionine free Dulbecco's. modified Eagle's medium (DMEM) supplemented with $1 \%$ fetal bovine serum and 0.5 millicuries of ${ }^{35} \mathrm{~S}$-methionine (New England Nuclear product NEG009T) was added to the culture. The culture was allowed to incubate 16 to 48 hcursto increase the amount of labeled viral proteins present in cells. The culture monolayer was rinsed once with plain DMEM to remove excess radiolabel and pelleted at 1000 rpm in a Beckman GPR centrifuge. The pellet was sonicated in $2-3 \mathrm{~mL}$ of lysis buffer $(0.8769 \mathrm{NaCl}$, 1.179 sodium EDTA, $0.48 \mathrm{~g}$ Tris, $0.5 \mathrm{~mL}$ NonIdet $\mathrm{P} 40$ in $100 \mathrm{~mL}$ distilled water; $\mathrm{pH}$ 7.0) for three 5 second pulses on ice 
followed by centrifugation at $134,000 \mathrm{~g}$ for 30 minutes. All antisera and monoclonal antibodies were similarly centrifuged to reduce the background on the final exposure of the dried gel to film.

Immunoprecipitation of Viral Proteins. Immunoprecipitation of viral proteins was carried out by washing and centrifuging fixed Staphvlococcus aureus cells (Calbiochem product \#507861)) three times in immune precipitation buffer (IPT) (0.1\% sodium dodecyl sulfate, $0.5 \%$ NonIdet P40, $0.2 \%$ deoxycholate, 10mM Triis, $0.15 \mathrm{M}$ sodium chloride, $\mathrm{pH}$ 8) to remove fines. The final pellet was resuspended to 10\% solids in IPT. For each sample, $100 \mu \mathrm{L}$ of staphylococcal protein $A$ was dispensed into a 12 X $75 \mathrm{~mm}$ tube. To immunoprecipitate the labeled nucleoprotein, $10 \boldsymbol{\mu L}$ of polyclonal monospecific anti-N antisera or $200 \mu \mathrm{L}$ of mixed monoclonal antibodies (consisting of $50 \mu \mathrm{L}$ each of hybridoma supernatant from 2NHIOSB, 1NC027G, 1NH163E and 1NDW14D) were added to the staphylococcal protein A. (Precipitation of the radiolabeled IHNV G proteins were similarly carried out, with the exception that the monospecific antiserum used was against the glycoprotein.) Antibody mixtures were allowed to incubate at $40 \mathrm{C}$ for 4 to 16 hours. Pellets were washed three ti mes with IPT buffer and centrifuged before the addition of antigen. One hundred to $500 \mu \mathrm{L}$ of antigen was added to the antibody charged pellets and the mixtures allowed to incubate at $4{ }^{\circ} \mathrm{C}$ for 4 to 16 hours. The pellets were washed three times with IPT buffer and were boiled in $75 \mu \mathrm{l}$ Laemmli sample buffer (Laemmli, 1970). 
Supernatants containing antigen were recovered from the pellets after centrifugation.

\section{Sodium Dodecyl Sulfate Polyacrylamide Gel}

Electrophoresis (SDS PAGE). Sodium dodecyl sulfate polyacrylamide gel electrophoresis was performed according to the methods of Laemmli (1970) with a 5\% stacking gel and a 13\% separating gel. Molecular weight standards (14C) were obtained from Amersham Corporation and included the following proteins: myosin, $200 \mathrm{kDa}$; phosphorylase B, $92.5 / 100 \mathrm{kDa}$; bovine serum albumin 69 kDa; ovalbumin, 46 kDa; carbonic anhydrase, 30 kDa; and Iysozyme, $14.3 \mathrm{kDa}$. Electrophoresis was performed at $10 \mathrm{~mA}$ until the bromophenol blue dye marker reached the bottom of the gel. The gel was fixed for one half hour in methanol: acetic acid: water/45:10:45, followed by immersion in Amplify (Amersham Corporation, Chicago, IL). The gel was dried for 2 hours on program 3 of a Model 543 gel dryer (BioRad, Richmond, CA). The dried gel was exposed to Kodak XLO film for 3 to 5 days and developed. Calculations of molecular weight were performed by using the molecular weight values supplied by the manufacturer of the standard (Amersham, Chicago, IL). For calculation of nucleoprotein molecular weights, a least squares equation was generated using the molecular weights of the ${ }^{14} \mathrm{C}$ standards (Amersham, Chicago 11): ovalbumin, 46 kDa; carbonic anhydrase, $30 \mathrm{kDa}$; and lysozyme, $14.3 \mathrm{kDa}$.

Fluorescence Analysis of Isolates. Isolates of IHNV were analyzed by indirect fluorescence with monoclonal antibodies 
made to the nucleoproteins and glycoproteins of the strains mentioned above. In order to perform the immunofluorescence assay, CHSE-214 cells were plated on glass coverslips deposited in 24-well tissue culture plates. Coverslips were then incubated with $0.2 \mathrm{~mL}$ of IHNV isolate and adsorbed at room temperature for one hour. One $\mathrm{mL}$ of complete medium RPMI 1640 supplemented with 10\% fetal bovine serum (FBS) was added and the cultures incubated for 20-24 hours at $16^{\circ} \mathrm{C}$. The coverslips were rinsed briefly in cold $\mathrm{PBS}$ and fixed in acetone at $4^{\circ} \mathrm{C}$. All fluorescence assays were performed in duplicate and were read by two individuals.

Coverslips were incubated with several drops of a predetermined dilution of monoclonal antibody for 30 minutes at $37^{\circ} \mathrm{c}$. They were rinsed thoroughly with calcium magnesium free phosphate buffered saline and the appropriate dilution of fluorescein conjugated rabbit anti-mouse immunoglobulin added and incubated for an additional 30 minutes. Coverslips were washed again and counterstained with $0.05 \%$ Evans blue for one minute and viewed under epifluorescence. A positive result was scored as brilliant apple green fluorescence on a red background.

Plaque Reduction Assay. Dilutions of virus and undiluted supernatant tissue culture fluid from hybridoma cultures containing monoclonal antibody were mixed on a shaker for three hours at $16^{\circ} \mathrm{C} . \quad$ EPC cells plated on 24-well tissue culture plates were the the indicator cell line. One-tenth $\mathrm{mL}$ of the 
antibody virus mixture was layered on the monolayer and the

cultures rocked for one hour at room temperature. Samples were then overlayed with Methocel in DMEM (Burke and Mulcahy, 1980). Plates were monitored for cytopathic effects, stained and the $\log _{10}$ neutralization index (difference in exponents of TCID50 titration with and without neutralizing monoclonal antibody) calculated.

Competition between Monoclonal Antibodies. In order to ascertain whether monoclonal antibodies mapped to the same site on the G protein of whole virus, a modification of the methods of Bricker et al. (1987) was employed. One hundred $\boldsymbol{\mu g}$ of purified monoclonal antibody was iodinated with carrier free sodium iodine (Na125I) (New England Nuclear product \# NEZ033A) in Iodogen coated tubes according to the methods described by the manufacturer (Pierce, Rockford, II). Excess free ${ }^{125}$ I was removed by passing the labeled antibody over a Sephadex G-100 column equilibrated in PBS. Briefly, $0.5 \mathrm{\mu g}$ of the virus was allowed to attach overnight in $0.2 \mathrm{M}$ sodium bicarbonate buffer, D:H 9.6, to each well of an Immulon I plate containing breakaway wells (Dynatech, Alexandria, VA). Plates were rinsed 3 times with phosphate buffered saline containing $0.05 \%$ Tween $20, \mathrm{pH}=7.4$ (PBST) to remove any unattached virus. Dilutions of an ${ }^{125} \mathrm{I}$ labeled monocloral antibody in 5\% bovine serum albumin in PBS were added to the plate in duplicate and incubated for two hours in order to determine the saturating concentration. A standard curve of antibody binding in counts per minute versus dilution was corstructed and the saturating concentration determined. 
The saturating concentration of antibody was mixed with $100 \mu \mathrm{g}$ of unlabeled competing antibody and the mixture added to the wells of the virus coated plate in a total volume of $200 \mu \mathrm{L}$. Each test was performed in duplicate and the entire assay performed twice. Incubation proceded for 2 hours, whereupon the plates were washed three times with PBST. The wells were broken apart and the individual wells counted in a gamma spectrometer. Percent inhibition of binding of the iodinated monoclonal antibody was calculated as follows:

Percent (cpm binding of antibody alone inhibition cpm of antibody binding in the

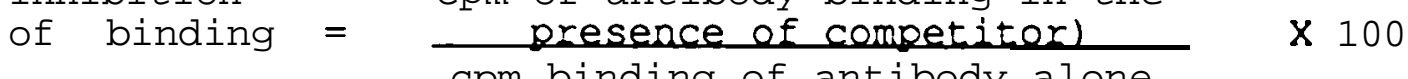
cpm binding of antibody alone If inhibition of binding in this test takes place at greater that 50\% level, the antibodies are considered to bind at approximately the same site. (Bricker et al., 1987).

RESULTS

\section{Serum Neutralization of 17 Isolates by Monoclonal}

Antibodies. All antibodies made to the glycoprotein of IHNV were tested for the ability to neutralize the virus. Within the group of antiglycoprotein antibodies, only five possessed serum redtralizing ability: 3GH127B, 3GH92A, 1GH131A, 3GH135I, and 2GH5F. The results of the neutralizations by the five antibodies are seen in Table 2 .

Twelve of the 17 isolates were neutralized by both of the monoclonal antibodies 3GH127B and 3GH92A. The five isolates not neutralized by the pair of antibodies were the "coastal" 
isolates: Coleman 1, Coleman 3, Cole Rivers, Elk River, and the 1982 Rangen Research isolate from the Hagerman Valley. Unique among the collection of seventeen isolates was a 1983 Hagerman isolate, 039-82SR, the only isolate which was neutralized by 1GH131A (Table 2). Neutralization of isolates by antibodies 3GH135I and 2GH5F was not significant. Two isolates taken at Round Butte Hatchery in 1989, one from steelhead (OF32) and the other from chinook salmon (OF52), were neutralized equally well by 3 GH92A and 3 GH127B.

The two antibodies, 3GH92A and 3GH127B, originally made to Hagerman isolate 039-82 SR, map to approximately the same site on this isolate, as seen in Table 3. Unlabeled 3GH92A was easily competed out by labeled 3GH127B. Likewise, unlabeled 3GH127B competed well with ${ }^{125}$ I labeled 3GH92A. Unlabeled 3GH127B, however, does not efficiently inhibit ${ }^{125} \mathrm{I}$ labeled 3GH127B. This result is difficult to reconcile but might be explained by the fact that $3 \mathrm{GH} 127 \mathrm{~B}$ is an IgM antibody and that iodination altered it to make it bind more efficiently than its unlabeled counterpart to the virus on the plate. Although the serum neutralization data in Table 2 strongly suggest that 3GH127B and 3GH92B see the same epitope on a number of isolates of IHNV, inspection of fluorescence data in Table 4 indicate that although all 17 isolates are positive with 3GH127B, only twelve are positive with 3GH92A. Warren Groberg (Oregon Department of Fish and Wildlife) has observed that a 1990 Hagerman Valley isolate, HV90, is neutralized by 3GH92A, but not 
by 3GH127B, also suggesting that there exists a difference in the specificity of the two antibodies.

Fluorescence Assays. The results of indirect fluorescence with monoclonal antibodies on the 17 selected isolates appears in Table 4. All of the isolates gave positive reactions with the anti-nucleoprotein antibodies, 1NDW14D (first column) and 1.NH139P (third column), both of which have identified more than 150 isolates of IHNV in our laboratory. With the monoclonal 2NH105B, which identifies electrophoretic type 2 IHNV (Ristow and Arnzen, 1989), there were nine positive reactions given by the following isolates: Cedar River 1989, Dworshak 1989, Hagerman 039-82 OSU, Hagerman 039-82 SR, Little White Salmon, Rargen Research, and three Round Butte Hatchery isolates. The earliest isolate from Round Butte from 1982 was negative, whereas the most recent three isolates were positive. With the Coleman 3 isolate, results were equivocal with antibody 2NH105B, with 1 to 5 cells being positive per coverslip. This result indicates that this isolate may be a "mixed" isolate. Only two of the seventeen isolates were positive with 2:NCO42C, an antibody originally made to the nucleoprotein of Coleman 2 IHNV, an electrophoretic type 4 IHNV (Hsu et al., 1986). Antibody 1GH151K was positive with only two isolates, the Hagerman isolate 039-82SR and the 1989 steelhead isolate from Round Butte. The two 1982 Hagerman 039-82 isolates from rainbow trout differ by reaction with two antibodies, 1GH15lK and 3FR23Q as well as by neutralization with antibody 1GH131A (Table 2) . 
All of the isolates, with the exception of Cedar River 1980, were negative with $1 \mathrm{NH} 17 \mathrm{~W}$, an antibody which was made to the nucleoprotein of Hagerman isolate 039-82 SR, and which has previously been shown to distinguish between the nucleoproteins of isolates within the same electropherotype (see Table 1 in the appendix). With antibody 2NDW18H, made to the nucleoprotein of the DW2 Dworshak isolate (Hsu et al., 1986), 11 of the seventeen isolates were positive. Like 1NH17W, 2NDN18H distinguishes between the nucleoproteins of isolates having the same electrophoretic type.

Of the total of 27 monoclonal antibodies, 12 were positive on all of the isolates. Anti-nucleoprotein antibodies which reacted with all 17 isolates were: 1NDW14D, 1NH163E, 1NH139P, 1NH104Q, 1NC013D, 1NDW19I, and 1NC027G. Likewise, the antiglycoprotein antibodies which reacted with all isolates were: 3GH136J, 3GH135L, 3GH127B, 1GCO6S and 1GCDR15A.

Although 3GH127B stained all 17 isolates in indirect fluorescence, it did not neutralize all of the isolates in the plaque neutralization studies. With respect to the fluorescence tests and reaction with the anti-glycoprotein antibodies, the Coleman 1, Coleman 3 and Elk River (all "coastal" isolates and chinook isolates) have the same glycoprotein fluorescence reaction pattern, although the reactions of their nucleoproteins differ. The 1989 Cole Rivers chinook isolate glycoprotein differs from the glycoproteins of the California Coleman isolates by a positive reaction with the 1GCDR1CB antibody. The two Cedar River sockeye salmon isolates are unique because they 
are the only isolates in the group which react with 1 GCDR2P, an antibody made to the glycoprotein of the 1980 Cedar River isolate from sockeye.

Of the two 1989 Round Butte Hatchery isolates studied, one from chinook and the other from steelhead, both had the same fluorescence patterns with the monoclonal antibodies with the exception that the steelhead isolate was weakly positive with 1GH151K. In fact, the 1983 and 1986 Round Butte steelhead isolates resembled the 1989 isolates with respect to most of the epitopes, with the exception that the 1983 isolate was negative with 2NH1C5B, indicating that it probably was not a Type II virus. Both older isolates were negative with 3FR230, while the 1989 isolates were positive.

\section{Molecular Weight Typing of Viral Nucleoprotein and Glycoprotein Polypeptides. Photographs of the} autoradiograms of the gels of the irrmuncprecipitation of the n.:cleoproteins by the mixture of anti-nccleoprotein antibodies (2NE105B, iNHC027G, 1NH163E AKD 1NDW14D) are found in Figures 1, 2, 3, and 4. Figures 1 and 2 are three-day exposures of the drie.d gel to XLO film, while Figures 3 and 4 are one day exposures. The molecular weight values found in Table 5 were calculated from Figures 3 and 4.

Molecular weights of the nucleoproteins of the various isolates found in Table 5 were calculated employing values of protein standards from Amersham Corporation. If alternate molecclar weights are employed for the standards in the caiculations, as performed by other investigators in previous 
publications (Hsu et al., 1986; Engelking and Leong, 1989), different molecular weights for the viral polypeptides are produced. The range of values obtained for this series of nucleoproteins was 41.2 to $42.4 \mathrm{kDa}$. The isolate having the largest molecular weight nucleoprotein was the Elk River isolate, while the molecular weights of the nucleoproteins of the other isolates varied from one another by tenths of a kilodalton.

Photographs of the immunoprecipitations of the $G$ proteins with rabbit anti-glycoprotein monospecific antisera are found in Figures 5, 6, and 7. Table 6 contains the molecular weights obtained from the central points of the autoradiographs of the glycoproteins. Molecular weights of the glycoproteins ranged from $67 \mathrm{kDa}$ to $71.5 \mathrm{kDa}$. Molecular weights were categorized as being either high ( $\mathrm{H}=70 \mathrm{kDa}$ or greater) or low ( $\mathrm{L}=$ less than $70 \mathrm{kDa})$. Not all of the glycoproteins of these isolates gave clear immuno-precipitation reactions. Immunoprecipitations of several of the isolates were repeated on separate gels (gels not pictured) and their glycoprotein molecular weights calculated. In these separate experiments, the molecular weights of the glycoproteins of the 1982 Dworshak isolate, the Little white Salmon isolate and the OF 52 Round Butte Hatchery isolate were confirmed on separate gels. However, there were four isolates which gave no precipitation in three separate experiments with the anti-glycoprotein monospecific antiserum. These were: Cedar River, 1989; Dworshak, 1989; Round Butte Hatchery (OF32), 1989 and Hagerman 039-82 OSU, 1982. Unique among all of the isolates 
were the Coleman 1 and Coleman 3 isolates and the Cole Rivers isolate, which possessed high molecular weight glycoproteins (Figure 5).

\section{DISCUSSION}

The data above indicate that a number of different forms of IHNV as judged by polypeptide analysis on SDS-PAGE, by serum neutralization, and by fluorescence analysis have existed inside and outside the Columbia River Basin within the past decade. In several respects, our results by serum neutralization, SDS-PAGE and fluorescence analysis agree with Hsu et al., e.g., the observation that two different species of fish, e.g., chinook salmon and steelhead in the same hatchery, (Round Butte, 1989), may be infected with the same virus. The fluorescence and serum neutralization analyses, however, revealed that two different forms of IHNV could also exist within a particular geographic area in the same year (e.g. the two Hagerman 1982 isolates). The SDS-PAGE method of typing virus, although it yields approximate molecular weight values for each isolate, is actually a very time consuming and expensive technique. At least a week's time is required to run the immunoprecipitation, prepare the samples for electrophoresis, run the electrophoresis, dry down the final product and autoradiograph the gel. The computations from the autoradiograph are subject to a number of errors, including the estimations of the distances traversed (rf values) for each of the polypeptides and errors introduced by drying the gel down to a fixed support. However, these 
experiments were included in this study because the SDS-PAGE method originally devised by Hsu et al. (1986) provided the first differentiation of IHN virus types. All of the ensuing studies utlizing monoclonal antibodies had to be compared to the electropherotypes to validate its own classification scheme.

Fluorescence analysis of an isolate is much faster and more economical, the infection of CHSE-214 cells requiring 24 hours. Staining is completed within several hours and the coverslips containing the stained infections read within a two hour period. It is more convenient to determine whether an isolate contains the epitope associated with Type 2 by staining a coverslip with 2NH105B, than it is to perform an immunoprecipitation with polyclonal antisera followed by SDS-PAGE and autoradiography. The utility of the monoclonal library for fluorescence analysis of some recent isolates is seen in Appendix Table 2.

We have found, as have Winton et al. (1988), that serum neutralization of isolates with anti-glycoprotein antibodies is a very valuable tool. This method is able to identify real differences in the neutralizing epitopes in the glycoprotein coat of the virus. Clearly, the Southern Oregon/California isolates (Cole Rivers, Elk River and the two Coleman isolates) are different from the majority of the isolates from the Columbia River Basin, with the exception of the Rangen Research isolate. Although an anti-glycoprotein monoclonal antibody in our collection stained with particular isolates in the fluorescence assay, the same antibody was not able to neutralize those isolates. (Notice, for example, the reactions of antibody 
3GH127B in Tables 2 and 4 with respect to the isolates of Coleman 1, Coleman 3 and cole Rivers). This indicates that a positive result obtained with a monoclonal antibody used against an isolate in a fluorescence assay does not necessarily correlate with a positive result in a neutralization assay.

The library of monoclonal antibodies described here can distinguish among the isolates when employed in all three techinques, and has the potential to assist hatchery managers and fish health personnel in making decisions concerning movement of eggs and stocks of fish. To summarize, certain of the anti-nucleoprotein antibodies in the library of monoclonals have shown themselves useful in distinguishing between groups of isolates. For example, the anti-nucleoprotein antibody 2NHIOSB identifies mainly the Type 2 IHNV as found in the Hagerman Valley and within the Columbia Basin, whereas anti-nucleoprotein antibody 2NC042C identifies an epitope originally associated with Coleman strains. It can be shown that the epitope identified by 2NCO42C is prevalent on the 1989 and 1990 isolates from chinook salmon at Coleman and is now appearing in other stocks (see the table of recent isolates in the appendix). The performance of the indirect fluorescence assay on cells on coverslips with either antibody is quite rapid, taking 16 hours (overnight) to infect cells with the isolate on coverslips plus several hours the next day to stain the coverslips with the antibodies and view the mounted coverslips under a fluorescence microscope. 
Neutralization of isolates with the antibodies 3GH92A and 3GH127B will generally distinguish between Southern Oregon/California isolates which are neutralized by the pair of antibodies, and the Columbia River Basin isolates which are not neutralized. (The exception to this finding in our study was the 1983 Rangen isolate). Neutralization with 3GH92A and 3GH127B could be performed in parallel to the standard plaguing technique which is already in place in many of the hatcheries in the Pacific Northwest.

In other related work with the antibodies, we have shown that the antibody INDW14D has been useful in the diagnosis of IHNV. The fluoresceinated anti-nucleoprotein antibody, 1NDW14D, universally recognizes IHNV in tissue culture 16 hours after infection, cutting the time for recognizing the presence of IHNV in ovarian fluids and spleen homogenates from 10 days to 16 hours (Ristow and Arnzen, 1989; Arnzen, Ristow, Poe and Lientz manuscript in press). This antibody does not crossreact with serotypes of VHSV, pike fry rhabdovirus, EVX (rhabdovirus of eels), or spring viremia of carp (P.E. Vestergaard-Jorgensen, personal communication). Also, when used in a dot immunoassay with an anti-nucleoprotein antibody prepared by Jorgensen's group against VHSV, 1P5B11, the pair of antibodies clearly distinguishes between IHNV and VHSV (Ristow, Lorenzen and Jorgensen, manuscript submitted) .

Thus, we believe that this collection of antibodies and certain of the antibodies in particular will be of value in the diagnosis and study of the epizootiology of IHNV. 


\section{LITERATURE CITED}

Bricker B. J., R. M. Snyder, J. A. Fox, W. A. Volk and R. R. Wagner. 1987. Monoclonal antibodies to the glycoprotein of vesicular stomatitis virus (New Jersey serotype): A method for preliminary mapping of epitopes. Virology 161:533-540.

Burke, J. A., and D Mulcahy. 1980. Plaquing procedure for infectious hematopoietic necrosis virus. Applied and Environmental Microbiology 39:872-876.

Engelking H. M. and J. C. Leong. 1989. The glycoprotein of infectious hematopoietic necrosis virus elicits neutralizing antibody and protective responses. Virus Research 13:213-230.

HsL, Y.-L., H. M. Engelking, and J. C. Leong. 1986. Occurrence of different types of infectious hematopoietic necrosis virus in fish. Applied Environmental Micrcbiology, 52: 1353-1361.

Laexmli, U.K. 1970. Cleavage of structural proteins during the assembly of the head of bacteriophage T4. Nature (London) $227: 680-685$.

LaFatra S. E., K. A. Roberti, J. S. Rohovec and J. L. Fryer. 1989. Fluorescent antibody test for the rapid diagnosis cf infectious hematopoietic necrosis. Journal of Aquatic Animal Health 1:29-36.

Ristow, S. S. and J. M. Arnzen. 1989. Development of Monoclonal Antibodies that recognize a Type 2 specific and a common epitope on the nucleoprotein of infectious hematopoietic necrosis virus. Journal of Aquatic Animal Health 1:119125.

Schultz C. L., B. C. Lidgerding, P. E. MCAllister and F. Hetrick. 1986. Production and characterization of monoclonal antibody against infectious hematopoietic necrosis virus. Fish Pathology 20: 339-341.

Winton J. R., Arakawa C. K., C. N. Lannan, and J. L. Fryer. 1988. Neutralizing monoclonal antibodies recognize antigenic variants among isolates of infectious hematopoietic necrosis virus. Diseases of Aquatic Organisms 4:199-204. 
TABLE 1

STRAIN

Cedar River

Cedar River

Coleman

Coleman

Cole Rivers

Dworshak

Dworshak

Elk River

Hagerman 039-82SR

Hagerman 039-82OSL

Little White Salmon

Metolius

Rangen Research

Round Butte Hatchery

Round Butte Hatcher>

Round Butte Hatchery

Round Butte Hatchery

\section{GEOGRAPHY}

Washington

Washington

California

California

Oregon

Idaho

Idaho

Oregon

Idaho

Idaho

Washington

Oregon

Idaho

Oregon

Oregon

Oregon

Oregon
HOST YEAR

ss $\quad 1980$

SS $\quad 1980$

CH 1982

$\mathrm{CH} \quad 1979$

CH 1989

sTS 1982

sTS 1989

CH 1982

RBT 1982

RBT 1982

$\mathrm{CH} \quad 1987$

KO 1989

RBT 1983

STS 1983

sTS $\quad 1986$

sTS 1989

CH 1989 
Table 2. Serum Neutralization

\begin{tabular}{|c|c|c|c|c|c|c|c|}
\hline Isolate & Species & Date & $3 G H 127 B$ & 3GH92A & 1GH131A & $3 \mathrm{GH} 135 \mathrm{~L}$ & 2GH5F \\
\hline Cedar River & ss & 1980 & 3.2 & 3.7 & - & 0.4 & - \\
\hline Cedar River & ss & 1989 & 3.1 & 3.8 & - & 0.6 & - \\
\hline Coleman 1 & ChS & 1982 & - & - & - & & - \\
\hline Coleman 3 & ChS & & & & - & & - \\
\hline Cole Rivers & ChS & 1989 & & & - & 0.6 & 0.1 \\
\hline Dworshak & sTS & 1982 & 3.4 & 4.4 & - & 0.6 & 0.5 \\
\hline Dworshak & sTS & 1989 & 3.5 & 3.9 & - & 0.5 & - \\
\hline Elk River & ChS & 1982 & & & - & 0.5 & - \\
\hline Hagcrman 039-82 SR & RbT & 1982 & 2.7 & 3.4 & 2.6 & 0.3 & - \\
\hline Hagerman 039-82 OSU & RbT & 1982 & 1.9 & 2.7 & - & - & \\
\hline Little White Salmon & ChS & 1987 & 2.9 & 4.5 & - & & \\
\hline Metolius & $\mathbf{K}$ & 1989 & 3.3 & 3.3 & - & 0.1 & \\
\hline Rangen Research & $\mathrm{RbT}$ & 1983 & - & & - & 0.1 & \\
\hline Round Butte & sTS & 1983 & 4.2 & 4.5 & - & 0.5 & - \\
\hline Round Butte & sTS & 1986 & 3.2 & 3.8 & - & 0.6 & - \\
\hline Round Butte & sTS & 1989 & 3.7 & 4.3 & - & 0.3 & - \\
\hline Round Butte & ChS & 1989 & 3.0 & 3.2 & - & & - \\
\hline
\end{tabular}


Table 3. Inhibition of 125I Labeled Antibodies.

Competing Antibodies

125| Labeled

Antibody

3GH92A

3GH127B

\begin{tabular}{cccc}
\hline 3GH92A & 3GH127B & IGH131A & 3GH135L \\
$97 \%$ & $94 \%$ & $46 \%$ & $35 \%$ \\
$93 \%$ & $62 \%$ & $11 \%$ & $0 \%$
\end{tabular}


Nomenclature for monoclonal antibodies. The numbering and lettering system on the library of monoclonal antibodies reads as as follows:

first numeral = fusion number

first letter $=G$ designates a fusion against the glycoprotein, while $\mathrm{N}$ designates a fusion against the nucleoprotein.

Abbreviations for virus to which the fusion was made: DW, Dworshak; H, Hagerman; FR, Feather River; CO, Coleman 2; CD, Cedar River.

number of cell line

last letter = clone designation

For example, the name of the monoclonal antibody 1NDW14D means an antibody which was made in the first fusion to the $\mathrm{N}$ protein of the Dworshak 2 IHNV, the 14th cell line, and the D clone (4th clone). 


\begin{tabular}{|c|c|c|c|c|c|c|c|c|c|c|c|c|c|c|}
\hline LOCATION & TYPE & DATE & $\begin{array}{c}\text { 1NDW } \\
140\end{array}$ & $\begin{array}{l}\text { 1NH } \\
163 E\end{array}$ & $\begin{array}{l}1 \mathrm{NH} \\
139 \mathrm{P}\end{array}$ & $\begin{array}{c}2 \mathrm{NH} \\
105 \mathrm{~B}\end{array}$ & $\begin{array}{c}1 \mathrm{NH} \\
1040\end{array}$ & $\begin{array}{c}\text { 1NCO } \\
13 D\end{array}$ & $\begin{array}{c}2 \mathrm{NCO} \\
42 \mathrm{C}\end{array}$ & $\begin{array}{c}\text { 1NDW } \\
191\end{array}$ & $\begin{array}{c}\text { 2NDW } \\
18 \mathrm{H}\end{array}$ & $\begin{array}{l}1 \mathrm{NH} \\
17 \mathrm{w}\end{array}$ & $\begin{array}{c}\text { 3NFR } \\
230\end{array}$ & $\begin{array}{c}1 \mathrm{NCO} \\
27 \mathrm{G}\end{array}$ \\
\hline Cedar River & SS & 1980 & + & + & + & & + & + & & + & & & & + \\
\hline Cedar River & SS & $19 \times 9$ & + & + & + & + & + & + & & + & & + & & + \\
\hline Colcman 1 & $\mathrm{CH}$ & 1980 & + & + & + & & + & + & + & + & & + & + & + \\
\hline Colcman 3 & $\mathrm{CH}$ & 1979 & + & + & + & * & + & + & + & + & + & + & + & + \\
\hline Cole Rivers & $\mathrm{CH}$ & 1989 & + & + & + & & + & + & & + & + & + & + & + \\
\hline Dworshuak & sTS & 1982 & + & + & + & & + & + & & + & & + & - & + \\
\hline Dworshak & sTS & 1989 & + & + & + & + & + & + & & + & + & + & - & + \\
\hline Elk River & cti & 1982 & + & + & + & & + & + & & + & & + & + & + \\
\hline Hagerman $039-82 S R$ & RIBT & 1982 & + & + & + & + & + & + & & + & + & + & - & + \\
\hline Hagerman $039-820 S U$ & RBT & 1982 & + & + & + & + & + & + & & + & + & + & + & + \\
\hline Little White Salmon & $\mathrm{CH}$ & 1987 & + & + & + & + & + & + & & + & + & + & & + \\
\hline Mctolius & KO & 1989 & + & + & + & & + & + & & + & & + & & + \\
\hline Rangen Research & RUT & 1983 & + & + & + & + & + & + & & + & + & + & & + \\
\hline Round Butte Ilatchery & sTS & 1986 & + & + & + & + & + & + & & + & + & + & & + \\
\hline Round Buttc Hatchery & sTS & 1983 & + & + & + & & + & + & & + & + & + & & + \\
\hline Round Bulte Halchery & sTS & 1989 & + & + & + & + & + & + & & + & + & + & + & + \\
\hline Round Butce Hatchery & $\mathrm{CH}$ & 1989 & + & + & + & + & + & + & & + & + & + & + & + \\
\hline
\end{tabular}




\begin{tabular}{|c|c|c|c|c|c|c|c|c|c|c|c|c|c|c|}
\hline $\begin{array}{l}3 \mathrm{GH} \\
136 \mathrm{~J}\end{array}$ & $\begin{array}{l}3 G H \\
135 L\end{array}$ & $\begin{array}{l}3 \mathrm{GH} \\
127 \mathrm{~B}\end{array}$ & $\begin{array}{l}1 \mathrm{GH} \\
131 \mathrm{~A}\end{array}$ & $\begin{array}{c}1 \mathrm{GH} \\
151 \mathrm{~K}\end{array}$ & $\begin{array}{l}3 \mathrm{GH} \\
92 \mathrm{~A}\end{array}$ & $\begin{array}{c}1 G C O \\
6 S\end{array}$ & $\begin{array}{l}\text { 2FR } \\
40 T\end{array}$ & $\begin{array}{c}\text { 1GCDR } \\
15 A\end{array}$ & $\underset{5 F}{2 G H}$ & $\begin{array}{l}1 \mathrm{GH} \\
111 \mathrm{~A}\end{array}$ & $\underset{2 P}{1 G C D R}$ & $\begin{array}{c}1 G C D R \\
10 B\end{array}$ & $\begin{array}{c}1 \mathrm{GCDR} \\
15 \mathrm{~B}\end{array}$ & $\begin{array}{c}1 \mathrm{GCDR} \\
2 \mathrm{~F}\end{array}$ \\
\hline+ & + & + & + & & + & + & + & + & + & + & + & + & + & + \\
\hline+ & + & + & - & & + & + & + & + & + & + & + & + & + & + \\
\hline+ & + & + & - & - & - & + & + & + & + & - & & & + & + \\
\hline+ & + & + & - & - & - & + & + & + & + & & & & + & + \\
\hline+ & + & + & & - & $\cdot$ & + & + & + & + & + & & + & + & + \\
\hline+ & + & + & + & & + & + & + & + & + & & & + & + & + \\
\hline+ & + & + & + & & + & + & & + & & + & - & - & - & \\
\hline+ & + & + & & - & . & + & + & + & + & & & & + & + \\
\hline+ & + & + & + & + & + & + & + & + & + & + & & & + & + \\
\hline+ & + & + & + & & + & + & + & + & + & + & & & + & + \\
\hline \multirow[t]{2}{*}{+} & + & + & wkt & & + & + & + & + & + & + & & + & + & + \\
\hline & + & + & + & & + & + & & + & + & + & & + & + & + \\
\hline+ & + & + & & - & - & + & + & + & + & + & & + & + & + \\
\hline+ & + & + & + & & + & + & + & + & + & + & & + & + & + \\
\hline+ & + & + & + & & + & + & + & + & + & + & & + & + & + \\
\hline+ & + & + & + & wkt & + & + & + & + & + & + & & + & + & + \\
\hline+ & + & + & + & & + & + & + & + & + & + & & + & + & + \\
\hline
\end{tabular}


Table 5. Nucleoprotein Molecular Weights

\section{LOCATION}

Cedar River

Cedar River

Coleman 1

Coleman 3

Cole Rivers

Dworshak

Dworshak

Elk River

Hagerman 039-82SR

Hagerman 039-82OSU

Little White Salmon

Metolius

Rangen Research

Round Butte Hatchery

Round Butte Hatchery

Round Butte Hatchery (OF32)

Round Butte Hatchery (OF52)
YEAR

1980

1989

1982

1979

1989

1982

1989

1982

1982

1982

1987

1989

1983

1983

1986

1989

1989
SPECIES MW

$\begin{array}{cc}\text { SS } & 41.3 \\ \text { SS } & 41.0 \\ \text { ChS } & 41.7 \\ \text { ChS } & 41.5 \\ \text { ChS } & 41.2 \\ \text { St } & 42.0 \\ \text { St } & 41.8 \\ \text { ChS } & 42.4 \\ \text { RBT } & 41.7 \\ \text { RBT } & 41.5 \\ \text { ChS } & 41.3 \\ \text { K } & 41.4 \\ \text { RBT } & 41.5 \\ \text { sTS } & 41.2 \\ \text { sTS } & 41.5 \\ \text { sTS } & 41.5 \\ \text { ChS } & 41.5\end{array}$

MW - Molecular weights caculated with Amersham standards 
Table 6. Molecular Weights of IHNV Glycoprotelns

\section{LOCATION}

Cedar River

Coleman 1

Coleman 3

Cole Rivers

Dworshak

Elk River

Hagerman 039-82SR

Little White Salmon

Metolius

Rangen Research

Round Butte Hatchery

Round Butte Hatchery

Round Butte Hatchery

Round Butte Hatchery (OF52)

\section{YEAR}

1980

1982

1979

1989

1982

1982

1982

1987

1989

1983

1983

1983

1986

1989
SPECIES

SS

ChS

ChS

ChS

St

ChS

RBT

ChS

$\mathrm{K}$

RBT

sTS

sTS

sTS

$\mathrm{ChS}$
MW

67.0

71.5

71.5

70.5

67.0

67.0

67.0

67.0

67.0

67.0

67.0

67.0

67.0

67.0
LOW OR

HIGH

L
H
H
H
H
L
L
L
L
L
L
L
L
L 
FIGURE LEGENDS

Figure 1. Nucleoproteins precipitated by monoclonal antibody mixture and electrophoresed on a 13\% gel. Order of electrophoresis: Lane $1,{ }^{14} \mathrm{C}$ standard; Lane 2, Cedar River 1980; Lane 3, Cedar River 1989; Lane 4, Cole Rivers; Lane 5, Coleman 1; Lane 6, Coleman 3; Lane 7, ${ }^{14} \mathrm{C}$ Standard; Lane 8, Dworshak 1980 ;

Lane 9, Dworshak 1989; Lane 10, Elk River. Photo is a 3 day exposure of Kodak XLO film to the gel.

Figure 2 Nucleoproteins precipitated by monoclonal antibody mixture and electrophoresed on a 13\% gel. Lane 1, 03982 SR; Lane 2, 03982 OSU; Lane 3, Little White Salmon; Lane 4, :etolius; Lane 5, Rangen Research; Lane 6, ${ }^{14} \mathrm{C}$ Standards; Lane 7, Round Butte Hatchery 1983; Lane 8, Round Butte Hatchery, 1986; Lane 9, Round Butte Hatchery (OF32), 1989; Lane 10, Round Butte Hatchery (OF52), 1989. Photo is a 3 day exposure of Kodak XL3 film to the gel.

Figure 3. Same as figure 1, except the exposure of the gel to the film is 24 hours.

Figure 4. Same as figure 1, except the exposure of the gel to the film is 24 hours.

Figure 5. Glycoproteins precipitated by monospecific antinucleoprotein antiserum and electrcphoresed on a 13\% gel. Crder of electrophcresis: Lane 1, Cedar Rïver 1980; Lane 2, 
Cedar River 1989; Lane 3, Cole Rivers; Lane 4, ${ }^{14} \mathrm{C}$ standards; Lane 5, Coleman 1; Lane 6, Coleman 3; Lane 7; Lane 8, Dworshak 1980;

Lane 9, Dworshak 1989; Lane 10, Elk River. Photo is a 3 day exposure of Kodak XLO film to the gel.

Figure 6. Glycoproteins precipitated by monospecific anti-nucleoprotein antiserum and electrophoresed on a 13\% gel. Lane 1, Hagerman 039-82 SR; Lane 2, Hagerman 039-82 OSU; Lane 3, Little White Salmon; Lane 4, Metolius; Lane 5, Rangen Research; Lane 6, ${ }^{14} \mathrm{C}$ Standards; Lane 7, Round Butte Hatchery 1983; Lane 8, Round Butte Hatchery, 1986; Lane 9, Round Butte Hatchery (OF32), 1989; Lane 10, Round Butte Hatchery (OF52), 1989. Photo is a 3 day exposure of Kodak XLO film to the gel.

Figure 7. Proteins of Cedar River 1980, Dworshak 1982, and Hagerman 039-82 SR immunoprecipitated by monospecific antiglycoprotein, anti-nucleoprotein and anti-whole IHNV antiserum on a 10\% gel. Cedar River 1980 immunoprecipitated by anti-whole IHNV (Lane 1), anti-nucleoprotein (Lane 2), and antiglycoprotein (Lane 3) antisera. Dworshak 2 immunoprecipitated by anti-whole IHNV (Lane 4), anti-nucleoprotein (Lane 5), and anti-glycoprotein (Lane 6), antisera. Hagerman 039-82 SR immunoprecipitated by anti-whole IHNV (Lane 7), antinucleoprotein (Lane 8), and anti-glycoprotein (Lane 9) antisera. Positions of ${ }^{14} \mathrm{C}$ standards are indicated at the right. 

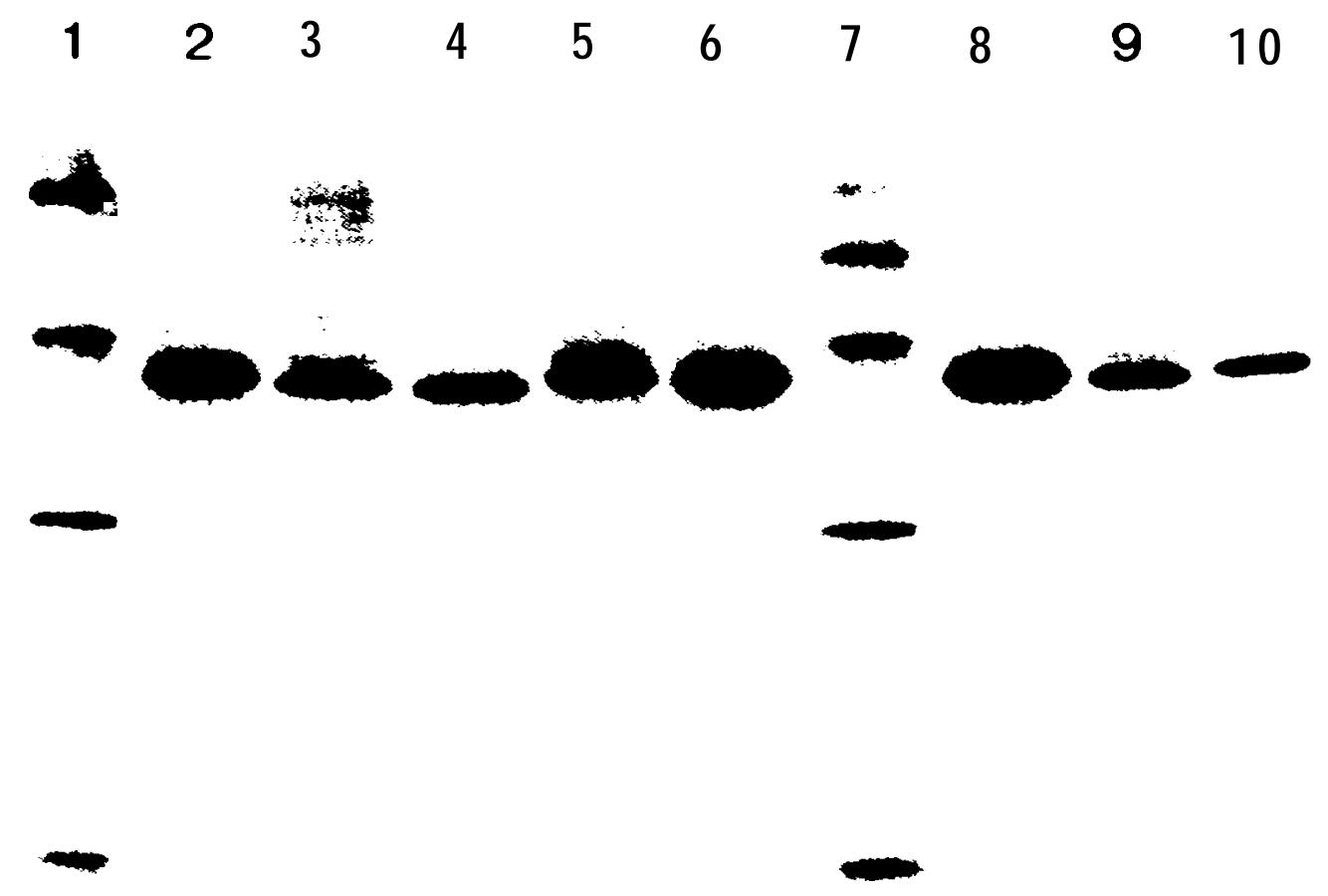


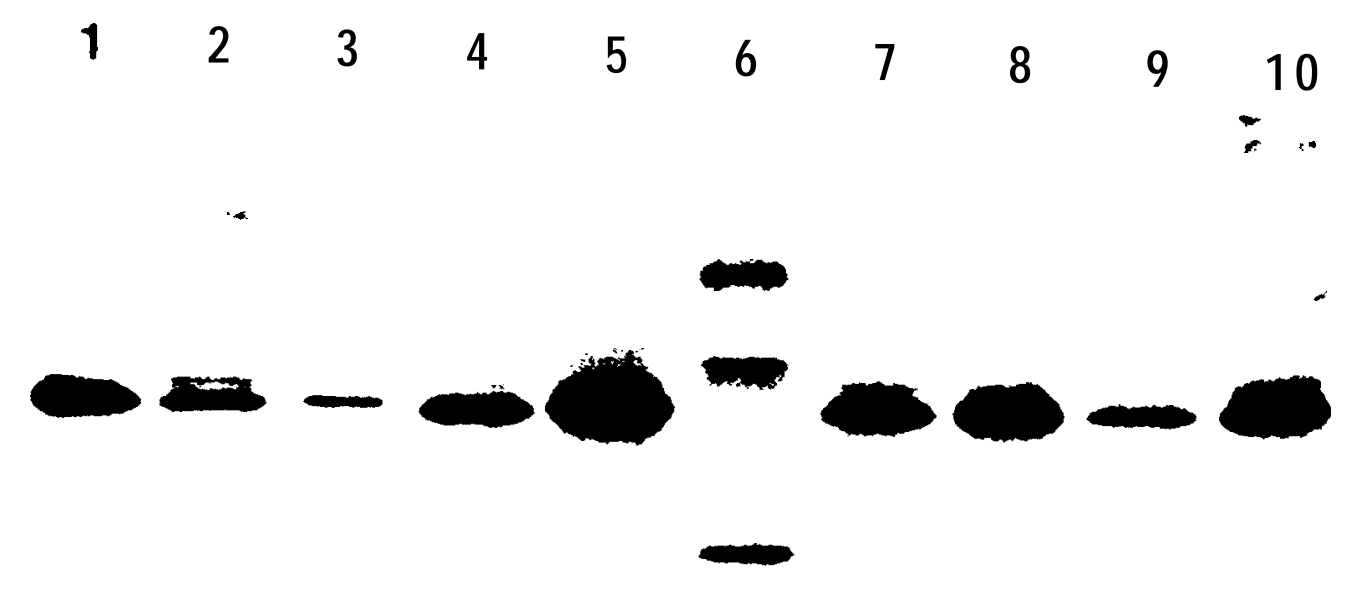

trom 
$\begin{array}{llllllllll}1 & 2 & 3 & 4 & 5 & 6 & 7 & 8 & 9 & 10\end{array}$

C... 


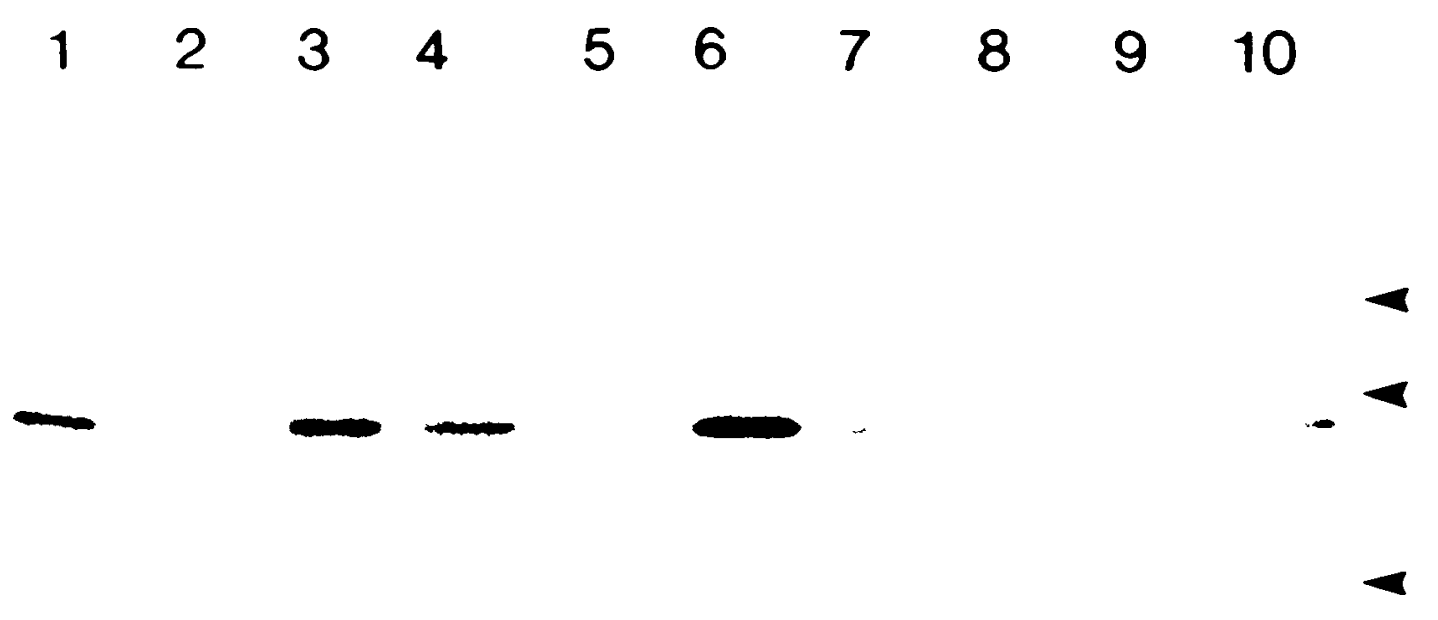




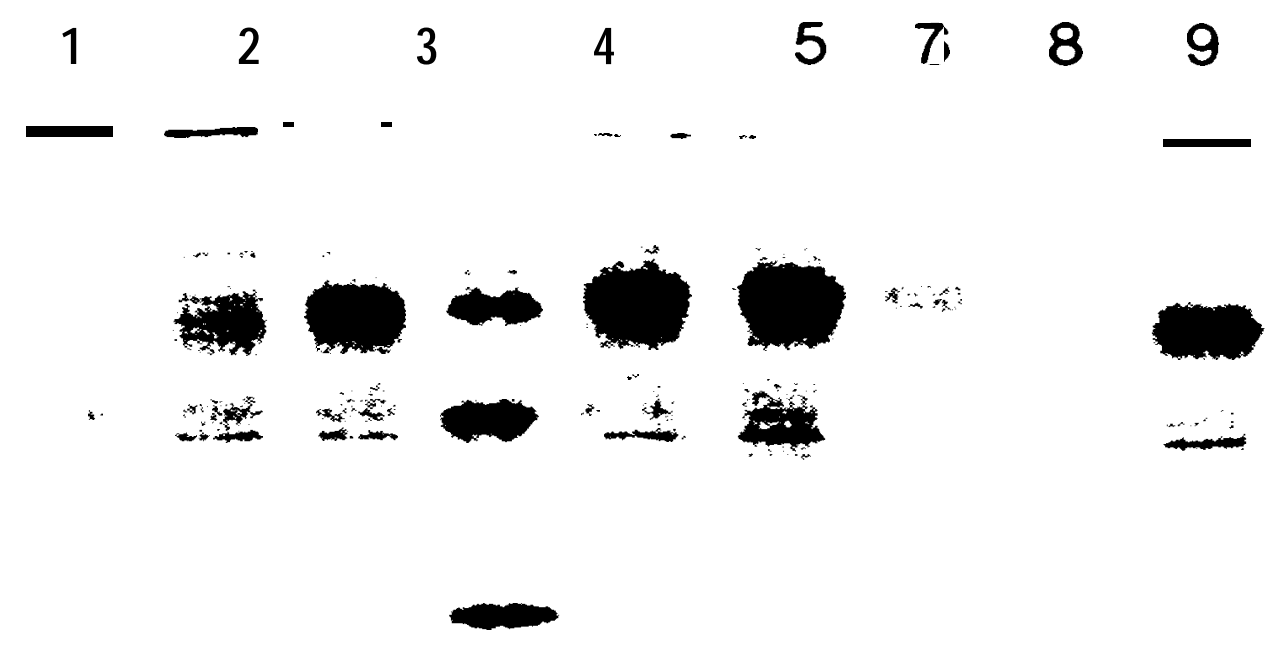




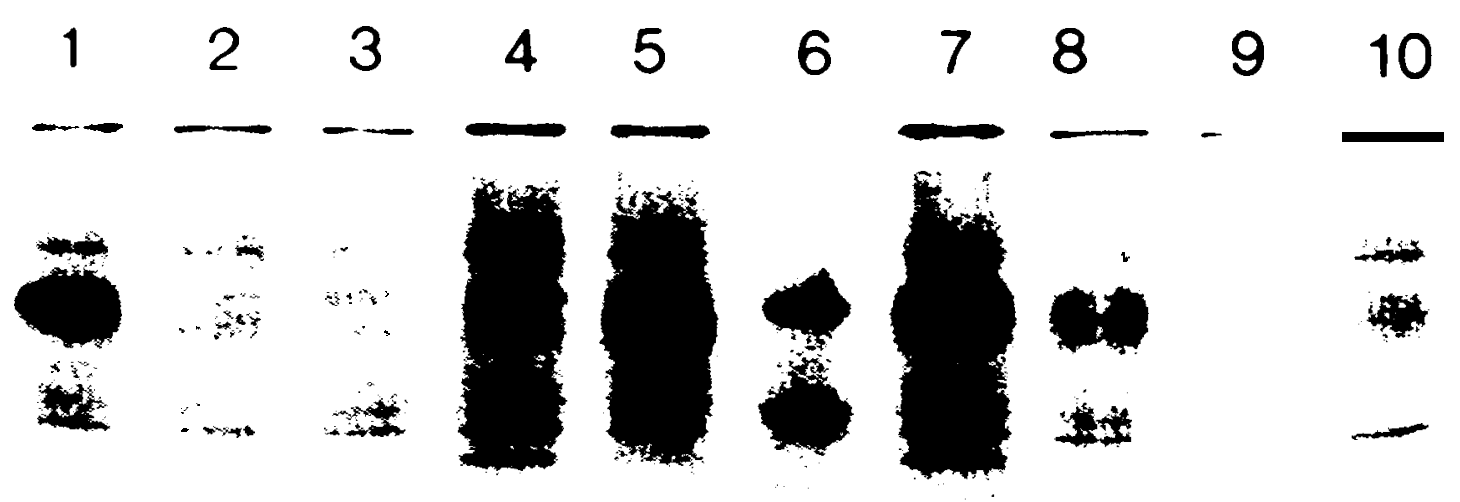




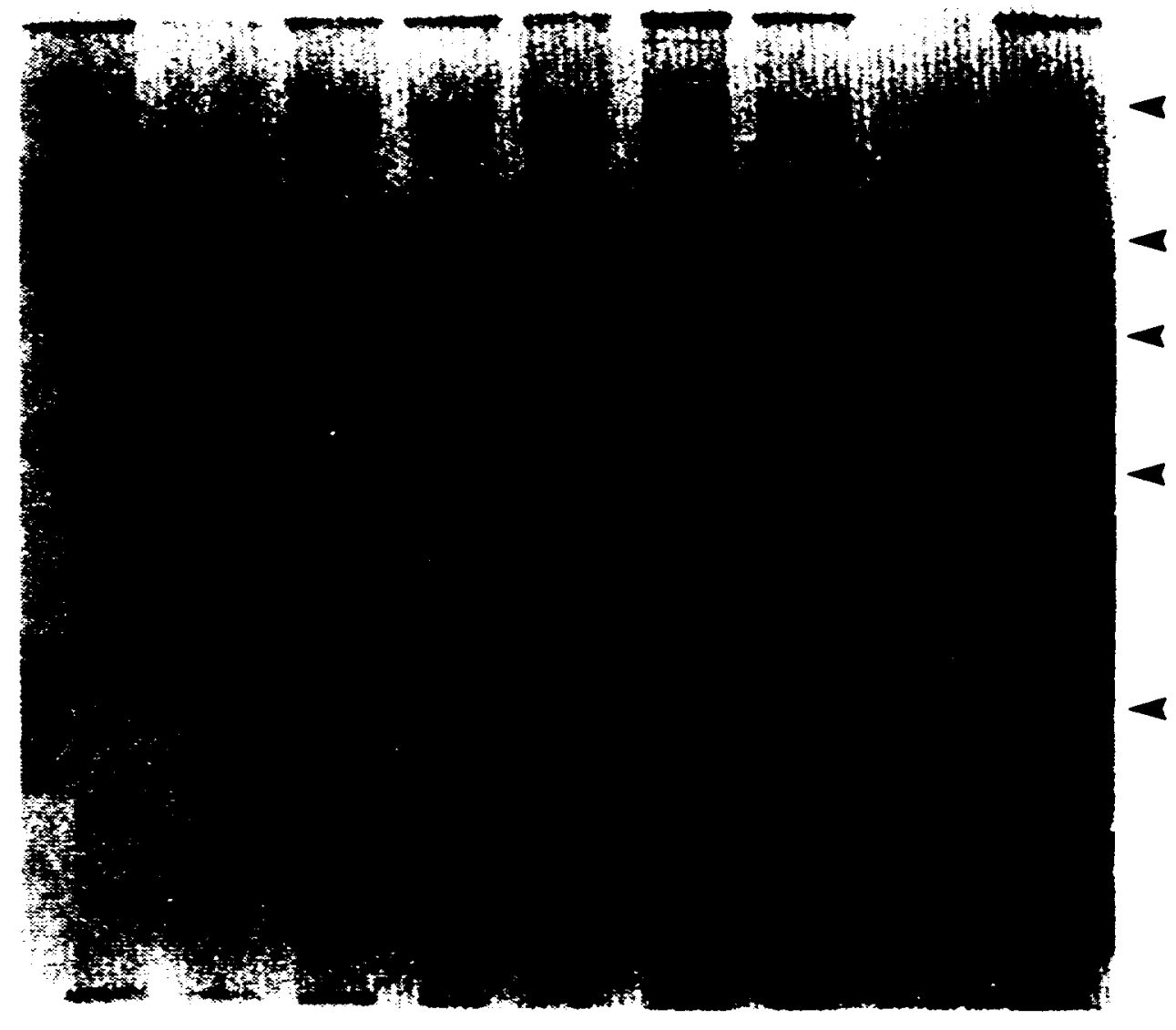


Appendix Table 1. A partial list of isolates from the paper by Hsu et al. (1986) analyzed by indirect fluorescence with five monoclonal antibodies made against the IHNV nucleoproteins (22JH105B， 2NC042C, 1NH17W，2NDW18H， 1NDW191) and 2 monoclonal antibodies produced against the glycoprotein (3GH127B and $1 \mathrm{GH} 131 \mathrm{~A})$.

Appendix Table 2. A tabulation of the reactions of recent isolates with a limited panel of antibodies in indirect fluorescence. Legend of antibodies: 131A = 1GH131A; 92A = $3 \mathrm{GH} 92 \mathrm{~A} ; 11 \mathrm{AA}=1 \mathrm{GHIllA} ; 127 \mathrm{~B}=3 \mathrm{GH} 127 \mathrm{~B} ; 2 \mathrm{~F}=1 \mathrm{GCDR} 2 \mathrm{~F} ; 5 \mathrm{~F}=$ $2 \mathrm{GHSF} ; 105 \mathrm{~B}=2 \mathrm{NH} 105 \mathrm{~B} ; 42 \mathrm{C}=2 \mathrm{NC} 042 \mathrm{C} ; 17 \mathrm{~W}=1 \mathrm{NH} 17 \mathrm{~W} ; 18 \mathrm{H}=$ 2NDW18H . 
TYPE I

$\begin{array}{lccc}\text { Bowron Lake } & & \text { SS } & 1976 \\ \text { Cameron Lake } & & \text { K } & 1978 \\ \text { Cowichan 1 } & & \text { SS } & 1978 \\ \text { Cultus Lake } & \text { SS } & 1978 \\ \text { Grt Central Lake } & \text { SS } & 1974 \\ \text { Weaver Creek 2 } & \text { SS } & 1976\end{array}$

\section{TYPE II}

Cowlitz 4

Cowlitz 5

Cowlitz 6

Hagerman 1

Hagerman 2

Mossy Rock

$\begin{array}{ccc}\text { St } & 1981 & + \\ \text { St } & 1981 & + \\ \text { Ct } & 1981 & + \\ \mathrm{RbT} & 1978 & + \\ \mathrm{RbT} & 1978 & + \\ \mathrm{St} & 1981 & +\end{array}$

\section{TYPE III}

Feather River

Nan Scott Lake

ChS 1977

RbT 1971

Sacramento Valley

Trinity River

ChS 1975

TYPE IV

Coleman 2

Coleman 3

ChS 1980

\section{TYPEV}

Cedar River

Karluk Lake

Karluk Lake

$\begin{array}{cc}\text { SS } & 1980 \\ \text { SS } & 1979 \\ \text { ChS } & 1979\end{array}$

* - 2 vials of Coleman 3 , one was positive on $2 \mathrm{NH} 105 \mathrm{~B}$, the other was negative. 


\section{RECENT ISOLATES}

\begin{tabular}{|c|c|c|c|c|c|c|c|c|c|c|c|c|}
\hline LOCATION & SPECIES & DATE & $131 \mathrm{~A}$ & $92 \mathrm{~A}$ & $111 \mathrm{~A}$ & 1278 & $2 F$ & $5 F$ & 105B & $42 \mathrm{C}$ & $17 w$ & $18 \mathrm{H}$ \\
\hline Dworshak OF \#470 & StT & $3 / 90$ & & + & + & + & & + & + & - & & + \\
\hline Hagerman Lot \#36 & StT & $3 / 90$ & & & + & + & + & \pm & + & - & + & + \\
\hline Hagerman Lot \#37 & StT & $3 / 90$ & & & + & + & + & + & + & - & + & + \\
\hline Hagerman Lot \#38 & StT & $3 / 90$ & & & + & - & - & & + & - & & + \\
\hline Hagerman Lot \#39 & StT & $3 / 90$ & & & + & + & + & + & + & $+/-$ & + & + \\
\hline Lyons Ferry & $\mathrm{RbT}$ & $8 / 89$ & & + & + & + & + & + & + & - & $*$ & + \\
\hline Warm Springs & $\mathrm{RbT}$ & $6 / 89$ & & + & \pm & + & + & + & + & - & + & + \\
\hline Little White Salmon & $\mathrm{ChS}$ & $5 / 89$ & & + & + & + & + & + & + & $+1-$ & + & + \\
\hline Coleman & $\mathrm{ChS}(\mathrm{F})$ & $10 / 89$ & + & - & + & + & + & + & - & + & + & + \\
\hline Coleman & $\mathrm{ChS}(\mathrm{LF})$ & $1 / 90$ & + & - & \pm & + & + & + & \pm & + & + & \\
\hline
\end{tabular}

